\title{
INTERNATIONAL COOPERATION IN FINANCIAL FRAUD INVESTIGATION
}

\author{
Volodymyr Ortynskyi ${ }^{1}$, Yuliia Chornous ${ }^{2}$, Nataliia Pavliuk ${ }^{3}$
}

\begin{abstract}
The aim of the article is to formulate theoretical principles and practical recommendations for the implementation of international cooperation in the investigation of financial fraud. The subject of the study is international cooperation in the investigation of financial fraud. Methodology. The research is based on the use of general scientific and special-scientific methods and techniques of scientific knowledge. The historical and legal method enabled to determine the preconditions for the origin of financial fraud as a crime of international nature, the establishment of the institute of international cooperation in criminal proceedings. The comparative legal method enabled to compare doctrinal approaches to the differentiation of tasks and forms of international cooperation in the investigation of financial fraud. The system-structural method enabled to determine the tasks of the pretrial investigation bodies in the investigation of financial fraud considering the functional aspect of the relevant bodies and individuals. The methods of grouping and classification were the basis for the author's approach to the definition of features of financial fraud as a crime of an international nature. The technical legal method enabled to examine the state of affairs in the legal regulation of the application of international cooperation measures in the investigation of financial fraud at the international and national levels, to identify its shortcomings, which determine the problems of practical implementation, to develop recommendations aimed at their elimination. The results of the study revealed that improvement of the international cooperation in the investigation of financial fraud involves the use of new methods and means of investigation (legal proceedings within the framework of international legal assistance, joint investigation teams, etc.); working out effective interaction with the competent authorities of foreign countries and international organizations. It is important to conclude international cooperation agreements, including interagency agreements; to improve the national legislation to comply with the provisions of international law; to harmonize the legislation of Ukraine and European states. Practical implications. In the research, financial fraud is defined as a crime of an international nature; the problematic issues of its investigation are determined; features of international cooperation in the investigation of financial fraud; the areas of its efficiency improvement are suggested. Relevance/originality. The original author's approach to the formulation of theoretical principles and practical recommendations for the implementation of international cooperation in the investigation of financial fraud is the foundation for the elaboration of the most promising areas for the development of national legislation and practical activities in this sphere.
\end{abstract}

Key words: financial fraud, investigation, international cooperation, international agreements.

JEL Classification: G15, F37

\section{Problem statement and its relevance}

The issues of international cooperation in the investigation of crimes of an international character are now the concern of scientists and experts. Modern economic crime causes enormous losses to the state, because of the possibility to destabilize the foundations of its socio-economic system. Its features are high latency, dynamism, and rapid adaptation to new conditions and business rules, the sustained nature of organized groups' activities in the form of criminal business under the cover of various market- based institutions, interregional and transnational criminal affiliations, and the application of effective means of counteraction to law enforcement bodies.

Nowadays, the problem of counteracting economic fraud in financial relations becomes very acute, because it poses a threat to different states and the entire world community, while its investigation necessitates implementation of measures of international cooperation.

\footnotetext{
Corresponding author:

${ }^{1}$ Institute of Jurisprudence and Psychology, Lviv Polytechnic National University, Ukraine.

${ }^{2}$ National Academy of Internal Affairs, Ukraine.

${ }^{3}$ Yaroslav Mudryi National Law University, Ukraine.
} 


\section{The aim and tasks of the study}

The aim of the article is to formulate theoretical principles and practical recommendations for the implementation of international cooperation in the investigation of financial fraud. To achieve this goal, the following tasks should be solved: to characterize financial fraud as a crime of an international nature; to identify the problematic issues of its investigation; to reveal specificities of international cooperation in the investigation of financial fraud; to suggest ways to improve its efficiency.

\section{The main material}

Financial fraud is a complex of interconnected and common by forensic features means of lucrative offenses against state financial resources, economic entities, and citizens via fraud and abuse of authority.

Financial fraud determines the specifics of modern economic crime and is fundamentally different from the previously known (traditional) ways of acquisition of someone else's property by a number of features, primarily:

1) financial fraud is based on specific techniques for misappropriation, that is, a complex of connected financial and related crimes consisting of the basic crimes (determining the content of technique of criminal activity for misappropriation); auxiliary (subordinate) crimes aimed at arranging, committing, and concealing crimes; supplementary (side) offenses committed at the same time taking into account factors relevant for the criminal-legal qualification, such as crimes related to the corruption of officials of public and private law;

2) financial fraud is committed in regulated by the rules of financial law relations concerning formation, distribution, redistribution, and use of financial resources of the state, economic entities and citizens;

3) financial fraud is committed by persons included in the system of connections and relations concerning the implementation of the financial and economic activity, which enables to use market institutions and financial instruments (fiscal relations, bank transactions, lending, investment, insurance, etc.);

4) financial fraud involves a clear algorithm of structured and skilfully managed acts of criminal behaviour (criminal schemes) concerning preparing, committing, and concealing crimes, characterized by the dynamics, rapid adaptation of criminals to changes in economic conditions and legislation;

5) technical coincidence of fraud preparation with legitimate financial and economic activities, as well as masking the signs of a crime under the civil-legal (economic) relationship at the stage of realization of criminal intent, complicates the detection of signs of crime by law enforcement bodies (Cherniavskyi, 2010).

Modern civilization, characterized by the acceleration of globalization and integration of the economies of individual countries into a single space, inevitably leads to the internationalization of crime. The latter becomes a factor that threatens the security of national economic systems. Financial fraud is a specific phenomenon in modern crime, as it manifests itself within individual states and, at the same time, covers the territories of many countries, becomes international in nature, is committed by transnational organized criminal groups. Therefore, the study of the specificities of combating fraud in individual countries, examination of the positive and negative aspects of legislative and enforcement practice, as well as countermeasures, are extremely important in international cooperation, because Ukraine is on the path of European integration and involved in European and global financial processes.

The international wrongfulness of financial fraud is defined by the provisions of international treaties (the UN Convention against Transnational Organized Crime of 2000 and the Protocols thereto (Konventsiia OON proty transnatsionalnoi orhanizovanoi zlochynnosti pryiniata rezoliutsiieiu 55/25 HA vid 15 lyst. 2000 roku), the Convention on Laundering, Search, Seizure and Confiscation of the Proceeds from Crime of 1990 (Konventsiia pro vidmyvannia, poshuk, aresht ta konfiskatsiyu dokhodiv, oderzhanykh zlochynnym shliakhom), the 1999 Criminal Law Convention on Corruption with the 2003 Additional Protocol (Konventsiia OON proty koruptsii), the UN Convention against Corruption of 2003 (Kryminalna konventsiia pro borotbu z koruptsiieiu), etc.). States undertook to make joint efforts to counteract various manifestations of financial fraud and related offenses.

Violations of financial legislation in most European states are criminalized by international regulations. In particular, the Convention on the Protection of Financial Intelligence of the European Union (1995) proposed to include in national laws a number of fraudulent delinquencies as unfavourable for the interests of the European Union. For example, the EU Council Framework Decision on combating fraud and counterfeiting of non-cash means of payment (2001) states that each state is obliged to criminalize intentional acts against bank payment facilities (Kachka, 2004).

Due to the recommendations of the European Union, the composition of criminal acts against the financial system in the legislation of European countries, as a rule, is carefully structured. However, there are some divergences in the legislation of the countries of the European Union regarding the definition of the concept and qualification of fraud.

Therefore, the criminal law of the majority of European Union countries provides for the following types of financial fraud: insurance, that is, a fraud committed to obtain the sum insured; banking, that is, a fraud aimed at the illegal obtaining of bank loans, other loans or property preferences; criminal bankruptcy, that is, a deception aimed at creating features of insolvency or 
unlawful actions in case of liquidation of an enterprise; tax, that is, a deception of the state and its bodies, such as illegal reduction of the total taxes to be paid, or refund of value added tax under export schemes; stock, that is, fraudulent actions on the securities market and in stock trading.

The analysis of law and its application in the United States of America is of particular interest as well. This country has faced financial fraud long before others and has gained some experience in counteracting this phenomenon. In the United States of America, criminal liability for property and economic crime is established both at the federal level and in individual states. However, economic crimes are criminalized mostly by federal legislation, which is related to the need of effective implementation of the United States obligations regarding the security of trade, financial system, etc. (Cherniavskyi, 2010).

Fraud in the US Federal Criminal Law is an extensive system of the most sophisticated and complex by form acts presented by schemes, techniques, methods, means, transactions, and performances that are of deceptive (fictional, imaginary, fictitious) nature encroaching on various objects (property, credit, banking and tax matters, relations in entrepreneurship and healthcare, etc.). Illegal operations via electronic computing form the so-called "computer" crimes, in which the computer is a means or tools for fraudulent misappropriation (Dementeva, 1992).

Therefore, financial fraud as an international crime is characterized by the following features: social danger, manifested in causing damage to economic relations; international wrongfulness, defined by international agreements and national laws of the states; investigation as a priority task of law enforcement bodies of states.

Financial fraud is a specific phenomenon in modern crime, because of manifestations both within individual states and in many countries if committed by transnational organized criminal groups. To counteract various forms of financial fraud effectively, international agreements have been concluded and implemented in accordance with the national legislation of the states. In the absence of an appropriate international agreement, the principle of reciprocity should be used.

Subjects of international cooperation can be divided into two groups, such as the authorized (central) and competent bodies of the states; international institutions and organizations.

During the investigation of financial fraud, law enforcement (competent) bodies cooperate in collecting evidence, exchanging evidence, guidance, background information, and other issues to fulfil the tasks of criminal proceedings.

Authorized (central) and competent state bodies are defined in international agreements and specified in the national legislation of the states. It is important that regardless of the definition in the legislation of a particular state of the bodies responsible for the implementation of measures of international cooperation ("law enforcement", "judicial authorities", etc.), in the international legal relations, they are defined as "authorized (central)" and "competent". This enables to use generic terms, which are specified in individual cases.

Considering the specificities of international cooperation in the investigation of financial fraud, the appropriate levels of its implementation can be defined. At the first level, there are joint activities of state bodies; bodies with the status of authorized (central) and competent; separate officials. These activities are aimed at forming the basis of cooperation.

At the second level of cooperation, specific practical tasks are implemented in the investigation of financial fraud. These are the coordinated activities of specific law enforcement bodies, their individual units and employees, such as investigators, operational workers, experts, prosecutors performing the tasks.

Under these conditions, cooperation is realized to exchange information of mutual interest; to search for persons hiding from criminal prosecution, as well as those who have disappeared untraceable; to search for items that are of interest to the investigation (forged documents and money, valuables, property, etc.); to plan and coordinate actions within the investigation; to exchange legal regulations, methodological recommendations, statistical information, work experience; to carry out scientific research and practical measures on counteraction to financial fraud and other forms of international crime.

International cooperation in the investigation of financial fraud involves the constant exchange of information. Mostly it concerns features of crime (committed or planned); physical persons and legal entities involved in the crime, as well as victims; structure, sphere of activity and links of an organized criminal group; items that are the subject of a criminal offense, are of interest to the investigation; traces of a crime, material evidence that may help to clarify the circumstances of the criminal proceedings, etc.

The procedural information exchange takes place within the framework of international legal assistance; in addition, the data obtained in this way (documents in accordance with the procedural form) are used for proving during the criminal proceedings by the competent authorities of the requesting state.

Non-procedural information exchange takes place between individual representatives of the competent authorities of the states. For example, it is employee consulting, background information provision. This information is briefing material predominantly that facilitates the adoption of procedural and tactical decisions.

Implementation of international cooperation in the investigation of financial fraud is characterized by specificities. The main of them include: 
- considering differences in the laws of the states and functioning of socio-economic institutions;

- regulation by international law and compliance with the principles of reciprocity and sovereignty of states; - the possibility of a refusal to execute the request in case of potential damage to the sovereignty, security of the state or other important interests; if the information requested relates to information constituting state secrets and for other reasons specified in international agreements and by national legislation;

- the geographical distance of subjects of interaction language and cultural differences, unusual features of procedural legislation of a foreign state (Nurbekov, 2012);

- special subjects of realization of the set tasks and used communication channels;

- long deadlines for fulfilling the tasks that should be considered when planning a financial fraud investigation; - independence of subjects of cooperation from each other, imperfect direct interaction;

- dependence of interaction outcomes on the completeness and reliability of briefing materials, preliminary preparation (Chornous, 2012).

A progressive form of international cooperation in the investigation of crimes is the creation and operation of international (joint) investigative teams.

In particular, according to Article 19 of the United Nations Convention against Transnational Organized Crime of 2000, in cases that are the subject of an investigation, prosecution or trial in one or more member states, the competent authorities involved may establish joint investigation bodies (in case of appropriate treaties or arrangements) (Konventsiia OON proty transnatsionalnoi orhanizovanoi zlochynnosti pryiniata rezoliutsiieiu 55/25 HA vid 15 lyst. 2000 roku).

According to Chapters 1-2 of Article 20 of the Second Additional Protocol of 2001 to the European Convention on Mutual Assistance in Criminal Matters of 1959, a joint investigation team may be set up where: a Party's investigations into criminal offences require difficult and demanding investigations having links with other Parties; several Parties conduct investigations into criminal offences, which circumstances require coordinated, concerted action in the Parties involved. A request may be made by any of the Parties concerned. The team is set up in one of the Parties, in which the investigations are expected to be carried out (Yevropeiska konventsiia pro vzaiemnu pravovu dopomohu u kryminalnykh spravakh 1959 roku ...).

The legislation of Ukraine provides for that in Ukraine, the General Prosecutor's Office of Ukraine is the body to make decisions on setting up a joint investigation team. The relevant provisions are in Part 2 of Article 571 of the Criminal Procedural Code of Ukraine (Kryminalnyi protsesualnyi kodeks Ukrainy...).

The Convention on Mutual Assistance in Criminal Matters between the Member States of the European
Union of 2000 provides for the possibility of the creation of joint investigation teams by the competent authorities of the member countries of the European Union for the implementation of specific measures for a specified period. In addition to representatives of the law enforcement agencies of the organization member states, which are a part of joint investigative teams, the possibility of involving employees of Europol and Eurojust is provided (Shostko, Ovcharenko, 2008).

In this respect, the signing and ratification of the Agreement on Operational and Strategic Cooperation between Ukraine and the European Police Office in 2016 (Uhoda mizh Ukrainoiu ta Yevropeyskym politseiskym ofisom pro operatyvne ta stratehichne spivrobitnytstvo vid 14 hrud. 2016 r.) is an important step, because Article 5 stipulates that Ukraine and Europol offer each other support in the setting up and operation of joint investigation teams.

Procedural, organizational, forensic principles of the setting up and functioning of joint investigative groups require the elaboration, development of an algorithm of action of law enforcement officers, conclusion of international interagency agreements between law enforcement agencies (Chornous, 2017), because this form of international cooperation is appropriate in the investigation of financial fraud.

A number of important tasks in the investigation of financial fraud can be solved with the help of international organizations.

A system of UN bodies has a number of institutions that contribute to the countering economic crime at the international level. In particular, the Centre for International Crime Prevention, the Financial Action Task Force on Money Laundering (FATF), the G8 Senior Experts Group on Transnational Organized Crime (the Lyon Group), the International Criminal Court, and others. At the regional level, the activity is coordinated by agencies set up within the Council of Europe.

The International Criminal Police Organization (Interpol) is of special importance among the global international organizations in countering international crime.

Interpol provides for countering such manifestations of international criminal activity as financial fraud, money laundering, transnational organized crime, tax evasion, non-return of foreign exchange earnings, legalization of vehicles, counterfeiting of credit cards, means of payment, securities and money, contraband, theft of state funds, banking crimes, corruption, crimes of officials, raiding, illegal interference in computer networks, malware (viruses) distribution, etc.

In the investigation of crimes, cooperation with Interpol is carried out mainly to exchange information; identification and verification of persons, items by accounting of Interpol and foreign police; to conduct international search through Interpol channels, 
to provide extradition; to assist in procedural actions within international cooperation.

Interpol requests enable to get information about the investigated financial fraud, such as illegal activities of entities; persons suspected of committing a crime and their links; seat or residence of suspects who have left abroad; the way of committing a crime, the circumstances of his commission; illegal activities of organized criminal groups; commercial structures, other legal entities located abroad involved in unlawful activities; the main areas of legal entities activity, their total authorized capital, information on their managers, founders; stolen vehicles and their owners; narcotic drugs, psychotropic substances, antiques, counterfeit documents, money and other objects related to the crime; analytical, scientific, statistical, and reference information on law enforcement activities, etc.

Interpol uses a number of tools to achieve its objectives. One of them is the use of the information retrieval system $1-24 / 7$, which is the global telecommunication system, based on the latest information technologies, provides high-quality and confidential round-the-clock direct access to the information resources of the General Secretariat of Interpol, and also allows the exchange of information between the NCB of Interpol of different states.

Interpol is equipped with a computerized Criminal Information System (ICIS), which enables to search for various information: identification of offenders, bank accounts used by them, names and addresses of legal entities involved in a crime. The automated search system (ASF) allows NCB of Interpol and the practical bodies to conduct an electronic search of certain information in data banks. This system enables to transfer images between the Interpol NCBs of different countries. Information and analytical support for Interpol are being carried out; in particular, the Analytical Criminal Intelligence (ACIU), staffed by qualified analysts, carries out its professional analysis (Chornous, 2012).

It is important to interact with Interpol in conducting procedural actions within the framework of international cooperation in criminal proceedings. However, these procedural actions are carried out via international legal assistance. Similarly, information on the persons, including citizens of Ukraine and legal entities, that open financial accounts with foreign banks, as well as the movement of funds, the conclusion of agreements between Ukrainian and foreign legal entities, constitute banking or commercial secrets and may be communicated to foreign the competent authorities only after considering the official appeal as international legal assistance.

In explicit cases, Interpol capabilities can be used to transfer requests for international cooperation. For example, Article 24 of the Convention on Laundering, Search, Seizure, and Confiscation of the Proceeds from Crime, 1990 (Konventsiia pro vidmyvannia, poshuk, aresht ta konfiskatsiyu dokhodiv, oderzhanykh zlochynnym shliakhom) states that any request or notification under paragraph 1 and paragraph 2 of this article (concerning a direct link between the central and judicial authorities) may be made through the International Criminal Police Organization (Interpol).

Another strategy of international cooperation in the investigation of financial fraud is connected with the European Police Office or Europol.

Europol is a specialized body of the European Union that coordinates the actions of the police and other competent authorities of the European Union, collects, analyses, and exchanges information on crimes and persons involved in their commission, performs other tasks. Europol is authorized to counter organized crime, terrorism, and other forms of serious crime, including the various forms of financial fraud affecting two or more Member States in a way that requires a common approach by the Member States, because of significance and consequences of such crimes (Uhoda mizh Ukrainoiu ta Yevropeyskym politseiskym ofisom pro operatyvne ta stratehichne spivrobitnytstvo vid 14 hrud. 2016 r.).

The basis of Europol's activities is the provision of information support for the cooperation of the competent authorities of the European Union countries in countering international crime. The information exchange system provides an opportunity for the Europol Member States to exchange information, necessary for conducting investigative and operational activities, with each other, Europol and third States in a secure mode. Europol cooperates with Interpol, as well as with other international organizations.

Europol operates in the member states of the European Union. Europol also cooperates with states that are not members. Therefore, on December 14, 2016, the Agreement on Operational and Strategic Cooperation (Uhoda mizh Ukrainoiu ta Yevropeyskym politseiskym ofisom pro operatyvne ta stratehichne spivrobitnytstvo vid 14 hrud. 2016 r.) was signed between Ukraine and the European Police Office, ratified by the Law of Ukraine on July 12, 2017.

Article 1 of the Agreement provides for that its objective is to establish cooperation between Ukraine and Europol to support Ukraine and the member states of the European Union in the prevention and countering organized crime, terrorism, and other forms of international crime. In accordance with the Europol Council Decision on the tasks of Europol, cooperation may include the exchange of information and expertise, general summaries, results of strategic analysis, information on criminal investigation procedures, information on methods of crime prevention, participation in trainings, as well as providing advice and support in selected criminal investigations (Uhoda mizh Ukrainoiu ta Yevropeyskym politseiskym ofisom pro operatyvne ta stratehichne spivrobitnytstvo vid 
14 hrud. 2016 r.). The Agreement will significantly strengthen the cooperation of the competent authorities of Ukraine with the European Police Office in countering financial fraud.

\section{Conclusions and perspectives of further research}

An international nature of financial fraud necessitates the improvement of the methodology of its investigation, including means of international cooperation for the accomplishment of the tasks.
The urgent tasks of improving international cooperation in the investigation of financial fraud are the use of new methods and means of the investigation (procedural actions within international legal assistance, creating joint investigation teams, etc.); effective interaction with the competent authorities of foreign countries and international organizations.

It is important to conclude international cooperation agreements, including interagency agreements; to improve national legislation compliant with the provisions of international law; to harmonize the legislation of Ukraine and European states.

\section{References:}

Cherniavskyi, S. S. (2010). Finansove shakhraistvo: metodolohichni zasady rozsliduvannia [Financial fraud: Methodological principles of investigation] (Monograph). Kyiv, Hi-Tech Press, 624 p. (in Ukrainian)

Konventsiia OON proty transnatsionalnoi orhanizovanoi zlochynnosti pryiniata rezoliutsiieiu 55/25 HA vid 15 lyst. 2000 roku [The UN Convention against Transnational Organized Crime, adopted by General Assembly Resolution 55/25 of November 15,2000]. (2006). Zbirnyk mizhnarodnykh dohovoriv Ukrainy pro pravovu dopomohu u kryminalnykh spravakh. Bahatostoronni dohovory. Kyiv. (in Ukrainian)

Konventsiia pro vidmyvannia, poshuk, aresht ta konfiskatsiyu dokhodiv, oderzhanykh zlochynnym shliakhom [The convention on laundering, search, seizure and confiscation of the proceeds from crime of November 8, 1990]. (2006). Zbirnyk mizhnarodnykh dohovoriv Ukrainy pro pravovu dopomohu u kryminalnykh spravakh. Bahatostoronni dohovory. Kyiv. (in Ukrainian)

Konventsiia OON proty koruptsii [Convention of the UN against Corruption of October 31, 2003]. (2010). Ofitsiynyi visnyk Ukrainy, 10, 506. (in Ukrainian)

Kryminalna konventsiia pro borotbu z koruptsiieiu (ETS 173) Dodatkovyi protokol [Additional Protocol to the Criminal Law Convention on Corruption of May 15, 2003]. (2006). Ofitsiynyi visnyk Ukrainy, 44, 2939. (in Ukrainian)

Kachka, T. (2004). Borotba z vidmyvanniam hroshei: kompleksnyi porivnialno-pravovyi analiz vidpovidnosti zakonodavstva Ukrainy acquis Yevropeiskoho Soiuzu u sferi borotby ta zapobihannia lehalizatsiyi dokhodiv, otrymanykh zlochynnym shliakhom [Combating money laundering: Comprehensive comparative legal analysis of the compliance of Ukrainian legislation with the acquis of the European Union in combating and preventing the legalization of proceeds from crime]. Kyiv, Referat, 288 p. (in Ukrainian)

Dementeva, E. E. (1992). Ekonomicheskaia prestupnost $i$ borba s nei $v$ stranakh s razvytoi rynochnoi ekonomikoi (na materialakh SSHA i Germanii) [Economic crime and struggle against it in the countries with developed market economy (on materials of the USA and Germany)]. Moscow, $240 \mathrm{p}$. (in Russian)

Nurbekov, I. M. (2012). Orhanyzatsiia i taktika vzaimodeistviia s inostrannymi kompetentnymi organami pri rassledovanii prestuplenii mezhdunarodnogo kharaktera [The organization and tactics of interaction with foreign competent authorities in the investigation of crimes of international character] (Monograph). Doctor of Law, Professor A. H. Volevodz (Ed.). Moscow, Yurlitinform, 248 p. (in Russian)

Chornous, Yu. M. (2012). Teoriia i praktyka kryminalistychnoho zabezpechennia dosudovoho slidstva u spravakh pro zlochyny mizhnarodnoho kharakteru [Theory and practice of forensic provision of pre-trial investigation in cases of crimes of an international nature]. Monograph. Kyiv, Skif, 448 p. (in Ukrainian)

Yevropeiska konventsiia pro vzaiemnu pravovu dopomohu u kryminalnykh spravakh 1959 roku z Dodatkovymy protokolamy 1978 ta 2001 roku do nei: ratyfikovana Zakonom Ukrainy vid 16 sich. 1998 r. [The European Convention on Mutual Assistance in Criminal Matters of 1959 with the Additional Protocols of 1978 and 2001 ratified by the Law of Ukraine of January 16, 1998]. (2006). Zbirnyk mizhnarodnykh dohovoriv Ukrainy pro pravovu dopomohu u kryminalnykh spravakh. Bahatostoronni dohovory. Kyiv. (in Ukrainian)

Kryminalnyi protsesualnyi kodeks Ukrainy [Criminal Procedural Code of Ukraine of April 13, 2012]. Retrieved from: http://zakon2.rada.gov.ua/laws/show/4651-17 (in Ukrainian)

Shostko, O. Yu., Ovcharenko, O. M. (2008). Prospects of cooperation of Ukraine with the European institutes in counteraction to organized crime. The Issue of Combating Crime: Collection of Scientific Works, 15, 110-122. Kharkiv. (in Ukrainian)

Uhoda mizh Ukrainoiu ta Yevropeyskym politseiskym ofisom pro operatyvne ta stratehichne spivrobitnytstvo vid 14 hrud. 2016 r. [Agreement on Operational and Strategic Cooperation between Ukraine and the European Police Office of December 14, 2016]. Retrieved from: http://zakon.rada.gov.ua/laws/show/984_001-16 (in Ukrainian) Chornous, Yu. M. (2017). Aktualni pytannia stvorennia i diialnosti mizhnarodnykh spilnykh slidchykh hrup [Topical issues of the creation and operation of international joint investigation teams]. Krymynalyst pervopechatnyi: mezhdunar. nauch.-prakt. yuryd. zhurn., 14, 36-47. Kharkiv. (in Ukrainian) 